AGRIEKONOMIKA

http://journal.trunojoyo.ac.id/agriekonomika

Volume 9, Nomor 2, 2020

https://doi.org/10.21107/agriekonomika.v9i2.8232
Agriekonomika has been accredited as a scientific journal by the Ministry of Research-Technology and Higher Education Republic of Indonesia: No. 23/E/KPT/2019

\title{
Produktivitas Usaha Mikro dan Kecil Industri Makanan di Indonesia
}

\author{
Syifa Fauziah, Amzul Rifin, Andriyono Kilat Adhi \\ Agribusiness Department Faculty of Economics and Management \\ Institut Pertanian Bogor, Indonesia \\ Received: Agustus 2020; Accepted: October 2020; Published: October 2020
}

\begin{abstract}
ABSTRAK
Kontribusi tenaga kerja pada UMK mencapai 93 persen dari total tenaga kerja yang ada. Kontribusi PDB nasional serta produksi usaha skala UMK juga terus mengalami pertumbuhan. Sementara industri makanan merupakan bagian dari industri pengolahan yang memiliki kontribusi pendapatan nasional paling besar dibanding industri lainnya. Disisi lain UMK yang termasuk ke dalam industri pengolahan juga mencapai lebih dari 90 persen. Tujuan penelitian ini untuk mengukur tingkat produktivitas usaha dan untuk mengetahui faktor apa saja yang mempengaruhi efisiensi usaha tersebut. Metode yang digunakan pada penelitian ini adalah analisis stochastic frontier. Responden yang digunakan sebanyak 2550 usaha. Hasil yang didapatkan sebagian besar usaha memiliki efisiensi yang tinggi secara teknis. Usaha dengan skala kecil memiliki tingkat efisiensi yang lebih tinggi dibanding usaha pada skala mikro. Untuk faktor yang diduga mempengaruhi efisiensi usaha diataranya adalah tingkat pendidikan, jumlah hari kerja dan jumlah jam kerja, sumber modal dan alokasi pemasaran.
\end{abstract}

Kata kunci: Analisis Stochastic Frontier, Efisiensi Teknis, Industri Makanan, Tenaga Kerja, UMKM.

Productivity on Micro and Small Enterprises in the Food Industry in Indonesia

\begin{abstract}
Micro and small enterprises (SMEs) has a contributes to economic growth. Labour contributions in SMEs even more than ninety percent of the total labour. While most of the SMEs is in the processing industry. The objectives of this research is to measure labour productivity and to know factors that affecting technical efficiency on SMEs in the food industry. Samples collected from the survey then were continued with cleaning data until 2250 unit of samples were taken. Technical efficiency and factors that affecting were described by quantitative analysis method Stochastic Frontier Analysis. Results showed that more than half of enterprises has a efficient. About seventeen percent of business that have below average in technical effficiency values. While small enterprises more technically efficient than micro enterprises. Level of education, working hours and working day, market alocation and variabel of percentage of own capital had a significant on technical efficiency.
\end{abstract}

Keywords: Food Industry, Labour, Micro Small Industry, Stochastic Frontier Analysis, Technical Efficiency. 


\section{PENDAHULUAN}

Skala Usaha Mikro dan Kecil (UMK) merupakan salah satu sektor usaha yang menarik untuk dibahas. Sektor ini memang memiliki skala yang kecil namun siapa sangka dibaliknya banyak peran yang sangat penting terutama sebagai sumber utama dalam penyerapan tenaga kerja dan salah satu sumber penting dalam pertumbuhan ekonomi. Menurut Kementerian Koperasi dan Usaha Kecil Menengah (2017), unit usaha yang ada pada sektor Usaha Mikro dan Kecil (UMK) bahkan mencapai 99 persen dari total unit usaha yang ada pada tahun 2018. Hal ini juga berbanding lurus dengan jumlah tenaga kerja yang berkontribusi pada sektor ini yaitu mencapai 93 persen. Besarnya jumlah tenaga kerja yang ada dikarenakan jumlah unit usaha yang ada pada sektor ini memang melimpah. Kontribusi sumbangan PDB nasional pada sektor UMK juga meningkat setiap tahunnya.

Menurut BPS (2017), Terkait dengan jenis usaha yang ada di Indonesia dibagi menjadi beberapa kategori, dalam menjalankan aktivitas ekonomi secara kuantitas usaha yang paling banyak dijalankan adalah pada kategori $G$ yaitu usaha perdagangan besar dan eceran, reparasi dan perawatan mobil dan sepeda motor yang jumlahnya mencapai 46.71 persen, kemudian jumlah terbanyak kedua adalah pada kategori I atau usaha penyediaan akomodasi dan penyediaan makan minum sebanyak 16.72 persen dan disusul oleh kategori $\mathrm{C}$ yaitu industri pengolahan yang jumlahnya mencapai 16.53 persen. Kemudian jika dilihat dari kontribusi pendapatan nasional berdasarkan beberapa jenis usaha tersebut kategori $C$ untuk industri pengolahan memang memiliki kontribusi tertinggi (Susianto dkk., 2019).

Industri pengolahan juga merupakan salah satu tulang punggung perekonomian Indonesia. Selain menciptakan nilai tambah industri ini juga menjadi andalan untuk penyerapan tenaga kerja. Selain itu jumlah tenaga kerja yang berkontribusi di industri pengolahan mencapai 22.75 persen dari total tenaga kerja yang ada. Sebesar 64.29 persen jumlah usaha industri pengolahan berada di pulau jawa, dan 37.57 persen diantaranya adalah industri pengolahan makanan dan minuman (BPS, 2017). Industri makanan dan minuman ini menjadi salah satu sektor unggulan di dalam sektor manufaktur di Indonesia. Menurut Susianto dkk. (2019), industri makanan dan minuman juga memiliki kontribusi PDB yang paling tinggi dibanding jenis usaha lainnya yang termasuk kategori $\mathrm{C}$ industri pengolahan. Selain itu menurut BPS (2017), jumlah UMK yang termasuk kategori industri pengolahan bahkan mencapai 99.04 persen.

Secara umum dapat diketahui bahwa jumlah unit usaha UMK ini memang mendominasi yang diikuti dengan kontribusi tenaga kerja yang melimpah dalam sektor ini, padahal jumlah pekerja yang ada pada setiap usaha UMK hanyalah sedikit. (Sholeh, 2017) mengatakan bahwa kontribusi pendapatan tenaga kerja UMK terhadap pendapatan keluarga sangat besar sehingga banyak tenaga kerja yang bergantung pada skala ini.

Pada Gambar 1 (a), dapat dilihat bahwa kontribusi pendapatan nasional secara berurutan adalah sektor usaha skala besar, skala mikro, menengah dan skala kecil. Perbedaan skala usaha sendiri di Indonesia telah diatur dalam UU No.20 tahun 2008 yang dapat dilihat dari perbedaan aset bersih dan omsetnya. Jika dilihat dari faktor tenaga kerjanya, tenaga kerja yang melimpah pada UMK secara keseluruhan seharusnya dapat meningkatkan pendapatan masyarakat pada sektor tersebut. Sementara jika dilihat pada Gambar 1 (b), pertumbuhan pendapatan nasional pada usaha UMK terus mengalami peningkatan yang positif. Gambar 2 bahkan menunjukkan bahwa pertumbuhan produksi usaha UMK pada industri makanan mengalami pertumbuhan yang cenderung positif.

Adanya peningkatan kontribusi pada sektor UMK terhadap pendapatan nasional atau perekonomian nasional 


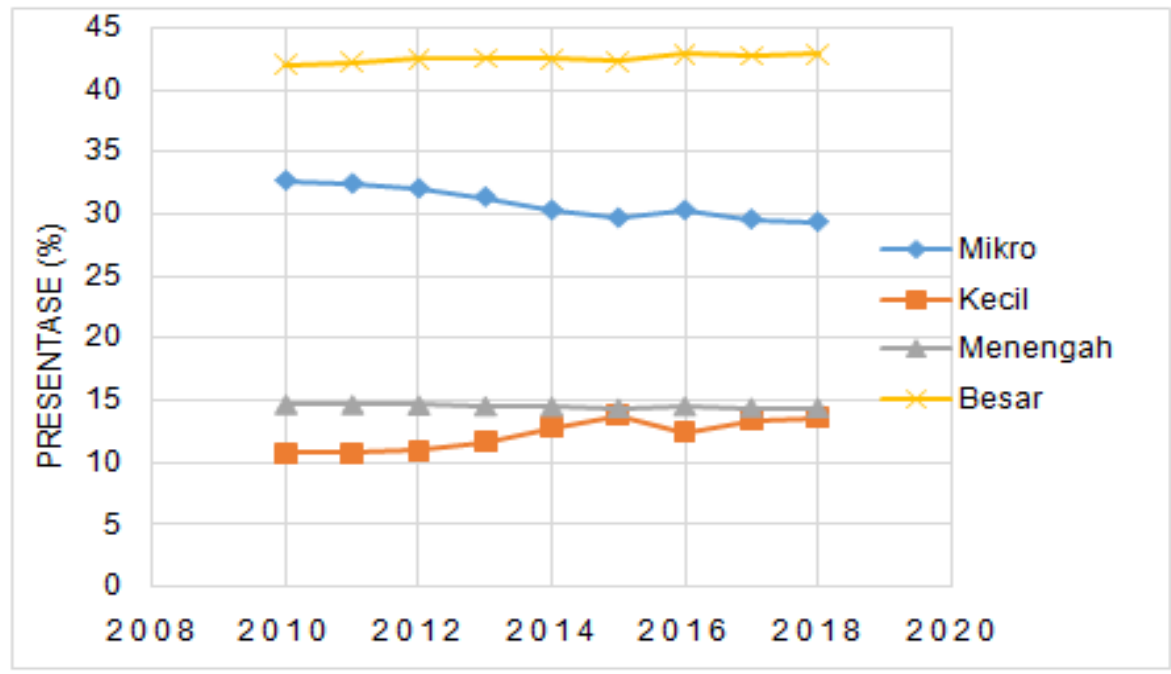

a

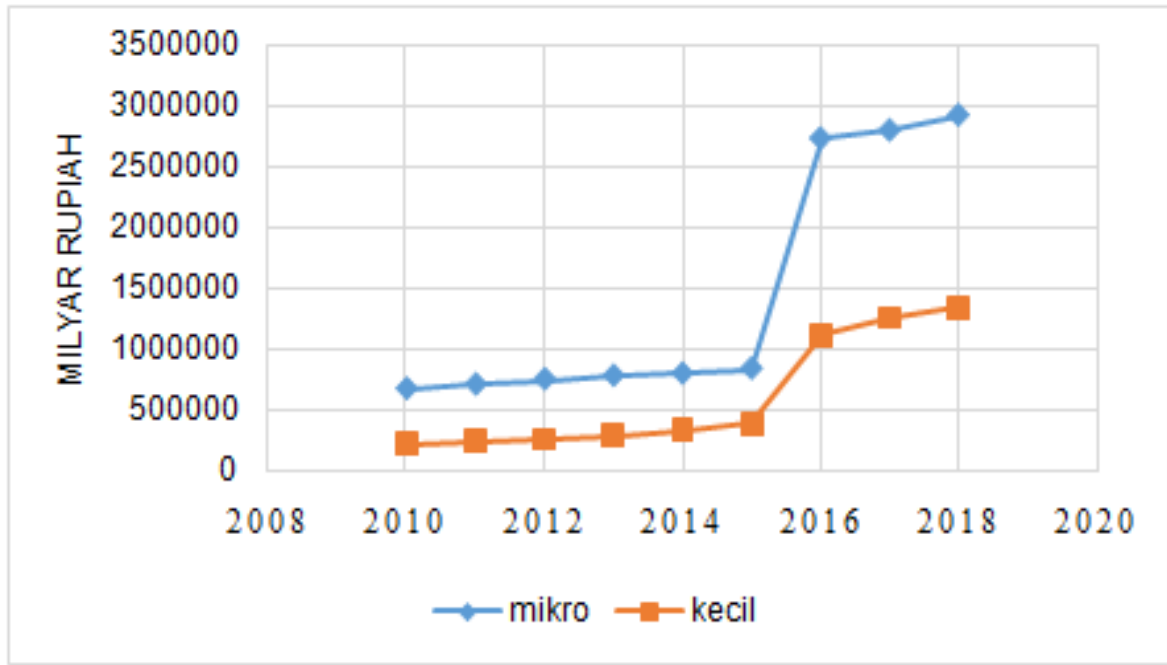

b

Sumber: Depkop, 2018 diolah

Gambar 1

(a) Persentase kontribusi usaha mikro, kecil menengah dan besar terhadap PDB nasional dan (b) Pertumbuhan GDP nasional pada sektor usaha mikro dan kecil

mengindikasikan bahwa UMK sudah mulai mampu menghasilkan pendapatan yang lebih tinggi. Salah satu kemungkinannya adalah produk yang dihasilkan menjadi lebih banyak. Banyaknya jumlah produk yang dihasilkan berkaitan dengan produktivitas usaha tersebut. Produktivitas usaha berkaitan dengan seberapa banyak produk yang dihasilkan dari setiap input yang ada, salah satu input penting dalam usaha skala mikro dan kecil adalah tenaga kerja. Kompetisi dan jaringan yang dimiliki menjadi faktor penghambat pertumbuhan UMKM (Andika \& Ardiyanti, 2014) sementara (Agung Pratama, 2015) mengatakan bahwa variabel modal yang merupakan faktor utama pertumbuhan UMKM.

Oleh karena itu pada penelitian ini ingin mengukur bagaimana tingkat efisiensi sebagai ukuran produktivitas usaha dalam UMK pada industri makanan 
di Indonesia? Selain itu penulis juga ingin mengidentifikasi faktor apa saja yang memengaruhi peningkatan produktivitas usaha UMK industri makanan di Indonesia agar usaha tersebut semakin efisien.

\section{METODE PENELITIAN}

Jenis data yang digunakan dalam penelitian ini adalah data sekunder. Data yang digunakan diperoleh dari data survei industri mikro dan kecil tahunan. Penelitian ini menggunakan data dalam Klasifikasi Baku Lapangan Usaha Indonesia (KBLI) untuk industri manufaktur (Kategori C) pada industri makanan dengan uraian 5-digit KBLI. Metode yang digunakan adalah metode probability sampling yaitu simple random sampling, Data yang digunakan terdiri dari 2550 responden yang terdiri dari responden yang memiliki usaha yang termasuk ke dalam kategori 5 digit KBLI pada industri makanan. Pengolahan data dilakukan secara kuantitatif. Saat pengolahan data dilakukan screening data (penghapusan data) dan juga transformasi data.

Penelitian ini dilakukan untuk melihat bagaimana efisiensi dari usaha mikro dan kecil sektor industri makanan yang ada di Indonesia. Untuk mengukur nilai efisiensi disini peneliti menggunakan nilai value added yang ada di setiap usaha tersebut sebagai ukuran dari nilai output yang dihasilkan. Nilai value added dapat diperoleh dari selisih nilai output produksi dengan nilai input yang berupa penggunaan bahan baku. Penggunaan nilai value added didasarkan karena output dari usaha pengolahan industri makanan adalah nilai tambah yang dihasilkan dari penggunaan input yang ada. Penelitian ini menggunakan metode stochastic frontier analysis untuk menghitung efisiensi dan untuk melihat faktor yang memengaruhi efisiensi usaha mikro dan kecil industri makanan di Indonesia.

Faktor yang diduga memengaruhi fungsi dari nilai tambah (value added) ini adalah modal, jumlah tenaga kerja, penggunaan air, dan energi (termasuk listrik, minyak dan gas). Penggunaan air dan energi dirasa penting khususnya untuk produksi dan operasional usaha sektor manufaktur industri makanan. Fungsi yang diduga adalah sebagai berikut.

$\ln Y i / L i=\ln \beta 0+\beta 1 \ln C i / L i+\beta 2 \ln W i / L i+$ $\beta 3 \ln \mathrm{Fi} / \mathrm{Li}+\beta 4 \ln \mathrm{Ei} / \mathrm{Li}$

Dimana Yi merupakan value added (rupiah), Ci adalah modal (rupiah), Li adalah jumlah tenaga kerja (orang), Wi adalah penggunaan air (rupiah), $\mathrm{Fi}$ adalah penggunaan bahan bakar minyak dan gas (rupiah) serta Ei adalah penggunaan energi listrik (rupiah).

Sementara untuk mengukur tingkat efisiensi teknis diatas dapat diukur dengan menggunakan rumus berikut.

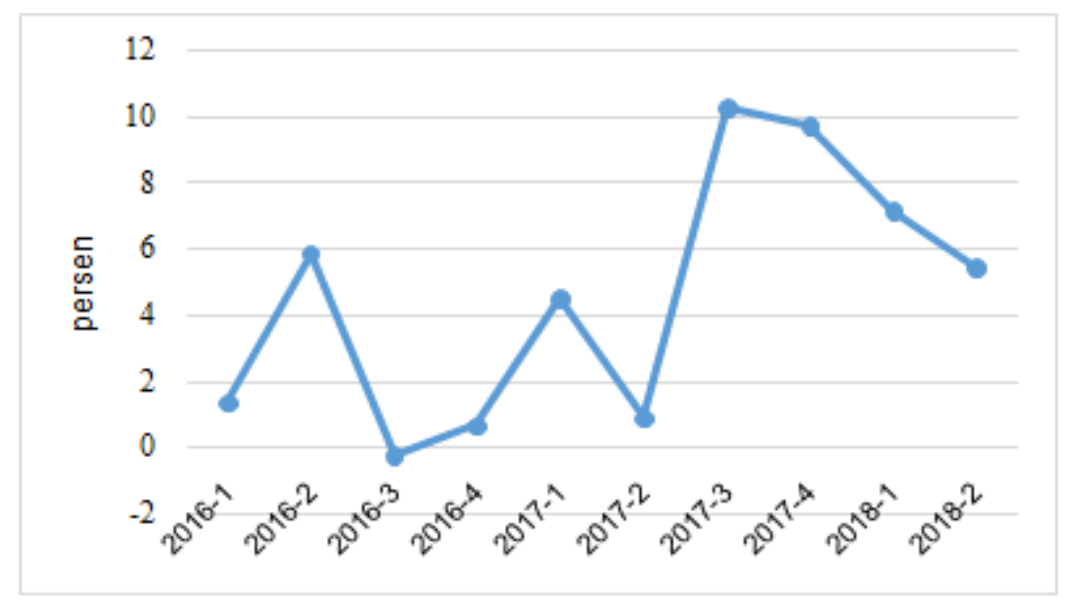

Sumber: BPS, 2018

\section{Gambar 2}

Pertumbuhan Produksi UMK Industri Makanan 
$\mathrm{TEi}=\exp (-\mathrm{E}[\mathrm{ui} \mid \varepsilon \mathrm{i}])$ dengan $0 \leq \mathrm{TEi} \leq 1$

Dimana TEi adalah efisiensi teknis usaha ke-l dan exp (-E[ui|ci]) adalah dugaan value added yang diperoleh dari value added stochastic frontier.

Nilai koefisien efisiensi teknis antara nol sampai dengan satu hanya digunakan untuk jenis data cross section. Nilai efisiensi teknis memiliki hubungan yang berbanding terbalik dengan nilai inefisiensi teknis. Untuk menentukan nilai parameter distribusi faktor inefisiensi teknis ini dianalisis lagi dengan cara sebagai berikut:

$$
\begin{aligned}
\mathrm{Ui}= & \alpha_{0}+\alpha_{1} Z_{1}+\alpha_{2} Z_{2}+\alpha_{3} Z_{3}+\alpha_{4} Z_{4}+\alpha_{5} Z_{5}+ \\
& \alpha_{6} Z_{6}+\alpha_{7} Z_{7}+\alpha_{8} Z_{8}+\alpha_{9} Z_{9}+v i
\end{aligned}
$$

Dimana Ui adalah efek inefisiensi teknis, $\mathbf{Z}_{1}$ adalah lama usaha (tahun), $\mathbf{Z}_{\mathbf{2}}$ adalah tingkat pendidikan (tahun), $\mathbf{Z}_{3}$ adalah dummy kemitraan (1=bermitra, $0=$ tidak bermitra), $\mathbf{Z}_{4}$ adalah alokasi pemasaran, $\mathbf{Z}_{5}$ adalah persentase modal sendiri, $\quad \mathbf{Z}_{6}$ adalah umur pengusaha (tahun), $\mathbf{Z}_{7}$ adalah jenis kelamin (1=lakilaki, $0=$ =perempuan), $\mathbf{Z}_{8}$ adalah jumlah hari kerja per bulan (hari) dan $\mathbf{Z}_{9}$ adalah jumlah jam kerja per hari (jam)

Nilai koefisien yang diharapkan adalah $\alpha<0$ agar berpengaruh negatif terhadap inefisiensi. Penentuan variabel didasarkan atas faktor yang sekiranya terkait dengan kinerja suatu usaha di usaha mikro dan kecil ini.

\section{HASIL DAN PEMBAHASAN}

Karakteristik Pemilik Usaha Mikro dan Kecil Industri Makanan

Karakteristik pemilik usaha terdiri dari beberapa variabel diantaranya adalah usia pemilik usaha, pendidikan formal, pengalaman usaha, keikutsertaan bermitra dan jenis kelamin. Usia dapat berhubungan dengan bagaimana seseorang dalam proses pengambilan keputusan. Pengusaha yang berada pada usia produktif tentunya akan berbeda perilakunya dengan pengusaha yang bukan merupakan usia produktif. Menurut Susianto dkk. (2019), usia produktif dikelompokkan menjadi dua kelompok yaitu usia sangat produktif dan usia produktif. Usia sangat produktif berada pada rentang usia 15-49 tahun dimana pada penelitian ini sebanyak 65.29 persen pengusaha berada pada rentang usia ini. Sementara responden yang berada pada usia produktif pada rentang usia 50-64 tahun ada sebanyak 30.07 persen dan sebanyak 4.62 persen memiliki usia lebih dari 64 tahun. Merujuk pada Tabel 1 ratarata usia responden baik untuk skala mikro maupun kecil termasuk pada kategori usia sangat produktif.

Tingkat pendidikan dapat berhubungan dengan kesempatan dan keputusan seseorang untuk bekerja pada sektor formal maupun informal. Semakin tinggi tingkat pendidikan seseorang maka kesempatan untuk bekerja diperusahaan akan semakin besar. Hal ini juga didukung oleh Arifin \& Firmansyah (2017), yang mengatakan bahwa tingkat pendidikan memiliki pengaruh negatif terhadap pengangguran. Persentase dari tingkat pendidikan responden secara keseluruhan paling banyak berada pada tingkat lulus SMA dengan jumlah 30.98 persen. Sementara responden yang ber-pendidikan sampai sarjana atau lebih hanya sekitar tiga persen dari total responden yang ada, Tabel 1 menunjukkan bahwa rata-

Tabel 1

Sebaran Responden Berdasarkan Karakteristik Pemilik Usaha

\begin{tabular}{lllll}
\hline & UMK & & Usaha Mikro & Usaha Kecil \\
\cline { 2 - 5 } Karakteristik & Minimum & Maksimum & Rata-rata & Rata-rata \\
\hline Usia pengusaha (tahun) & 19 & 82 & 45.58 & 47.56 \\
Pendidikan (tahun) & 5 & 18 & 8.74 & 9.87 \\
Pengalaman (tahun) & 1 & 76 & 12.91 & 12.83 \\
\hline Sung
\end{tabular}


rata pendidikan pengusaha skala kecil lebih besar dibanding skala mikro. Utari \& Dewi (2014) dan Robleh (2017), juga mengatakan bahwa tingkat pendidikan berpengaruh signifikan terhadap kinerja UMKM.

Pengalaman usaha menunjukkan seberapa lama pelaku usaha berada pada lingkungan tersebut. Semakin lama seseorang berada pada usaha tersebut semakin banyak pula pengalaman yang bisa ia dapatkan, sehingga pengalaman usaha dapat juga dilihat dari lamanya mereka berusaha. Furqon (2018), juga mengatakan bahwa lamanya usaha memiliki pengaruh yang positif terhadap pendapatan usaha pada tingkat UMKM. Sementara Leza dkk. (2016) dan Pilar dkk. (2018), mengatakan umur usaha memiliki pengaruh yang signifikan terhadap efisiensi usaha. Sebaran responden menunjukkan bahwa sekitar 49.68 memiliki pengalaman usaha kurang dari sepuluh tahun. Sementara merujuk Tabel 1 ratarata lamanya usaha untuk skala mikro maupun kecil tidak berbeda jauh.

Adanya kemitraan merupakan salah satu cara untuk membantu setiap usaha khususnya usaha mikro dan kecil. Kemitraan dapat dilakukan dengan berbagai pihak untuk mengurangi kendala yang ada di perusahaan. Menurut Fanani dkk. (2015), motif adanya kerjasama atau kemitraan adalah dapat mengurangi risiko dan melengkapi kemampuan, selain itu adanya kemitraan juga dapat membantu dalam kendala keuangan. Merujuk Tabel 2, kemitraan banyak dilakukan oleh pengusaha kecil dibanding usaha mikro, namun secara keseluruhan UMK didominasi oleh para pengusaha yang tidak pernah bermitra yaitu mencapai 92.5 persen. Alasan mereka untuk tidak bermitra juga cukup beragam, mulai dari yang tidak tahu prosedur, tidak berminat dan tidak paham. Padahal menurut Quinn dkk. (2014) dan Soriano dkk. (2019), kemitraan memengaruhi kinerja usaha pada skala mikro dan kecil.

Pada penelitian ini pelaku usaha kecil yang berjenis kelamin perempuan lebih mendominasi dibanding dengan pengusaha yang berjenis kelamin laki-laki, namun sebaliknya dengan usaha kecil. Namun jika dilihat secara keseluruhan tujpilaruh puluh satu persen usaha UMK industri makanan ini didominasi oleh perempuan. Lebih banyak perempuan dapat dikatakan karena usaha ini merupakan usaha pengolahan industri makanan dan sebagian besar produknya adalah berbagai jenis roti, kue basah maupun kue kering. Menurut Kadim dkk. (2017), perbedaan jenis kelamin tidak memiliki pengaruh yang signifikan terhadap pendapatan suatu usaha. Demikian menurut Septiana (2018), variabel jenis kelamin juga tidak berpengaruh terhadap produktivitas usaha mikro.

\section{Karakteristik Usaha Mikro dan Kecil Industri Makanan}

Karakteristik usaha terdiri dari beberapa variabel diantaranya jumlah tenaga kerja, jam kerja per hari serta hari kerja per bulan, sumber modal dan nilai aset,

Tabel 2

Karakteristik Pemilik Usaha Berdasarkan Kemitraan dan Jenis Kelamin

\begin{tabular}{lcccc}
\hline Karakteristik & \multicolumn{2}{c}{ Usaha Mikro } & \multicolumn{2}{c}{ Usaha Kecil } \\
\cline { 2 - 5 } & Jumlah (orang) & Persentase (\%) & Jumlah (orang) & Persentase (\%) \\
\hline Kemitraan & 165 & 6.98 & 26 & 13.82 \\
Bermitra & 2197 & 93.01 & 162 & 86.17 \\
Tidak Bermitra & & & & \\
Jenis Kelamin & 610 & 25.82 & 117 & 62.23 \\
Laki-laki & 1752 & 74.17 & 71 & 37.77 \\
Perempuan & & & &
\end{tabular}

Sumber: Data Primer Diolah, 2020 
lalu terkait nilai tambah perusahaan, konsumen utama dan alokasi pasar serta terkait penggunaan input bahan bakar, listrik dan air. Perhitungan jumlah tenaga kerja pada penelitian ini termasuk dengan pemilik usaha itu sendiri. Usaha dengan satu orang tenaga kerja mencapai 25.84 persen dari total responden sementara ada sekitar 23.84 persen usaha menggunakan dua tenaga kerja, lalu sekitar 24.86 persen usaha dikerjakan oleh tiga sampai lima orang tenaga kerja. Merujuk Tabel 3 ratarata penggunaan tenaga kerja usaha kecil lebih besar dibanding usaha mikro. Perbedaan UMK selain berdasarkan omset dan modal yang dimiliki juga dapat dilihat dari jumlah pekerjanya. Semakin tinggi skala usaha tenaga kerjanya juga semakin banyak. Sementara menurut Purwanto dkk. (2014) variabel jumlah tenaga kerja memengaruhi tingkat efisiensi usaha kecil dan menengah.

Berdasarkan jumlah hari kerja per bulan terakhir perusahaan tersebut berproduksi rata-rata jumlah hari kerja adalah 23 hari. Sebanyak 68.07 persen responden bekerja dengan waktu lebih dari tiga minggu setiap bulannya. Sementara terkait dengan jam kerja per hari rata-rata keseluruhan yang bekerja adalah 6.52 jam per hari. Namun merujuk Tabel 3 rata-rata jumlah hari kerja dan jam kerja pada usaha skala kecil lebih besar dibanding usaha mikro.

Sementara terkait sumber modal usaha, sebagian besar pengusaha mengaku bahwa sumber modal mereka adalah dari biaya sendiri secara penuh, sebanyak 84.58 persen usaha mikro dan 62.23 persen usaha kecil menggunakan modal usaha dengan biaya sendiri tanpa sumber modal dari orang lain. Variabel modal memiliki pengaruh yang signifikan terhadap produktivitas dan efisiensi produksi usaha kecil dan menengah (Ariani \& Suresmiathi (2013); Agustin dkk. (2018); Alna dkk. (2018)). Óhegyi dkk. (2013), Cherkos dkk. (2018), dan Kinyua (2014), juga mengatakan kemudahan pembiayaan berpengaruh terhadap kinerja usaha UMKM. Hidayati (2016), juga mengatakan UMKM cenderung memiliki keterbatasan dana sehingga seringkali terkendala dalam pemasaran dan kalah dalam bersaing. Terkait dengan nilai aset (modal) yang terdiri dari aset lancar maupun aset tetap. Aset lancar meliputi uang tunai termasuk piutang usaha dan nilai dari persediaan barang untuk kegiatan usaha, sementara harta tetap merupakan nilai dari tanah bangunan ataupun barang lainnya yang digunakan untuk kegiatan perusahaan rata-rata total aset secara keseluruhan adalah sekitar 94 juta rupiah. Sementara sebesar 62.43 persen responden memiliki nilai aset kurang dari 50 juta rupiah. Merujuk pada Tabel 3 rata-rata aset usaha kecil memang memiliki nilai yang lebih besar dibandingkan usaha mikro.

Nilai tambah perusahaan memiliki rata-rata sekitar lima juta rupiah per bulannya. Tabel 3 menunjukkan perbedaan nilai tambah yang diperoleh oleh usaha kecil pun jauh lebih besar dibandingkan

Tabel 3

Karakteristik Responden Berdasarkan Usaha UMK Industri Makanan

\begin{tabular}{lcccc}
\hline & Usaha Mikro & Usaha Kecil & \multicolumn{2}{c}{ UMK } \\
\cline { 2 - 5 } Karakteristik & Rata-rata & Rata-rata & Minimum & Maksimum \\
\hline Jumlah tenaga kerja (orang) & 2.01 & 7.59 & 1 & 19 \\
$\begin{array}{l}\text { Jumlah hari kerja per bulan } \\
\text { (hari) }\end{array}$ & 23.01 & 24.01 & 1 & 31 \\
$\begin{array}{l}\text { Jumlah jam kerja per hari } \\
\text { (jam) }\end{array}$ & 6.38 & 8.27 & 1 & 24 \\
$\begin{array}{l}\text { Nilai asset (ribu rupiah) } \\
\text { Nilai tambah (rupiah) }\end{array}$ & 79468 & 285055 & 10 & 8995000 \\
\hline
\end{tabular}

Sumber: Data Primer Diolah, 2020 
usaha mikro. Lalu terkait dengan konsumen utama untuk usaha skala mikro sebagian besar menjual produknya untuk kebutuhan pedagang dan rumah tangga, sementara usaha kecil untuk keperluan pedagang. Selain itu terkait alokasi pasar utama usaha UMK sebanyak 95.42 persen usaha mikro hanya menjual produk dalam lingkup kabupaten, sementara untuk usaha kecil 79.78 persen dalam kabupaten dan sebagian lainnya untuk lingkup luar kabupaten dan luar provinsi, dapat dilihat sebaran alokasi pasar usaha kecil juga lebih luas dibanding usaha mikro.

Terkait penggunaan bahan bakar, listrik dan air untuk operasional usaha sebagian besar usaha hanya menggunakan input tersebut dengan nilai kurang dari dua ratus ribu setiap bulannya. Selain itu dalam penelitian ini usaha industri makanan terdiri dari beberapa bagian yang dapat dilihat menurut kode digitnya, dan sekitar 81.37 persen usaha berada pada industri roti, kue dan masakan lainnya.
Terkait sebaran responden berdasarkan alokasi pasar utama dapat dilihat pada Tabel 4. Berdasarkan Tabel 4 dapat diartikan bahwa sebagian besar responden masih menjual produknya hanya dalam lingkup kabupaten saja. Sementara terkait sebaran berdasarkan sumber modal utama dapat dilihat pada Tabel 5 dimana sebagian besar responden menggunakan modal sendiri untuk modal usahanya.

\section{Hasil Uji Analisis Data \\ Uji Diagnostik Model}

Uji diagnostik yang dilakukan pada penelitian ini adalah uji multikolinearitas, karena variabel telah terbebas dari asumsi klasik lainnya terkait heteroskedastisitas dan normalitas. Peneliti menggunakan alat regresi robust sehingga dihasilkan model yang resisten terhadap outlier. Selain itu uji multikolinearitas dilakukan dengan uji VIF dimana hasilnya dari seluruh variabel nilai VIF kurang dari sepuluh, dengan kata lain tidak ada hubungan antar variabel

Tabel 4

Sebaran Responden Berdasarkan Alokasi Pasar Utama

\begin{tabular}{lcccc}
\hline Alokasi Pasar & \multicolumn{2}{c}{ Usaha Mikro } & \multicolumn{2}{c}{ Usaha Kecil } \\
\cline { 2 - 5 } & Jumlah (orang) & Persentase (\%) & Jumlah (orang) & Persentase (\%) \\
\hline Dalam & 2285 & 96.74 & 162 & 86.17 \\
kabupaten & & & & \\
Luar Kabupaten & 66 & 2.79 & 19 & 10.10 \\
Luar Provinsi & 11 & 0.46 & 7 & 3.72 \\
Total & 2362 & & 188 & \\
\hline
\end{tabular}

Sumber: Data Primer Diolah, 2020

Tabel 5

Sebaran Responden Berdasarkan Persentase Modal Usaha

\begin{tabular}{lcccc}
\hline Sumber modal & \multicolumn{2}{c}{ Usaha Mikro } & \multicolumn{2}{c}{ Usaha Kecil } \\
\cline { 2 - 5 } & 1998 & 84.58 & 117 & 62.23 \\
\hline $\begin{array}{l}\text { Seluruhnya } \\
\text { sendiri }\end{array}$ & 78 & 3.30 & 10 & 5.31 \\
$\begin{array}{l}\text { Seluruhnya dari } \\
\text { pihak lain }\end{array}$ & 286 & 12.10 & 61 & 32.44 \\
$\begin{array}{l}\text { Ada bantuan } \\
\text { Total }\end{array}$ & 2362 & & 188 & \\
\hline
\end{tabular}

Sumber: Data Primer Diolah, 2020 
dan telah memenuhi syarat untuk analisis regresi berganda berdasarkan Ordinary Least Square.

\section{Uji Regresi Berganda}

Pada penelitian ini untuk menghitung nilai efisiensi dan melihat faktor yang memengaruhinya, sebelumnya dilakukan uji regresi untuk melihat faktor yang memengaruhi fungsi dari nilai tambah (value added) per tenaga kerja. Hasil output dari model regresi nilai tambah per tenaga kerja dapat dilihat pada Tabel 6.

\section{Efisiensi Teknis dari Nilai Tambah per Tenaga Kerja}

Hasil dari sebaran nilai efisiensi tambah per tenaga kerja dapat dilihat pada Tabel 7 dimana usaha yang sudah efisien lebih dari 90 persen bahkan mencapai 59.17 persen. Perusahaan yang memiliki nilai efisiensi paling kecil adalah usaha dengan kode digit 10792 yang merupakan industri kue basah, Sementara nilai efisiensi terbesar berada pada jenis usaha dengan kode digit 10631 atau termasuk industri penggilingan padi dan penyosohan beras. Hanya sekitar 17 persen usaha yang memiliki nilai efisiensi teknis kurang dari rata-rata keseluruhan.

Pada Tabel 8, dapat dilihat bahwa industri dengan kode digit 106 atau industri penggilingan padi memiliki ratarata efisiensi tertinggi dibanding dengan rata-rata efisiensi pada jenis usaha yang lainnya. Namun setiap jenis usaha telah memiliki rata-rata efisiensi lebih dari 80 persen.

Merujuk Tabel 9, nilai rata-rata dari efisiensi setiap tenaga kerja untuk kedua skala sudah cukup tinggi. Namun nilai rata-rata efisiensi untuk skala usaha kecil memiliki nilai yang lebih besar yaitu sekitar sembilan puluh lima persen dibandingkan dengan nilai usaha pada skala mikro dengan rata rata efisiensi sekitar delapan puluh sembilan persen. Perbedaan yang

Tabel 6

Hasil Output Model Nilai Tambah per Tenaga Kerja

\begin{tabular}{lll}
\hline Variabel & Koefisien & P-value \\
\hline Modal per tenaga kerja & $0.0456^{* * *}$ & 0.0000 \\
Penggunaan bahan bakar per tenaga kerja & $0.4747^{* * *}$ & 0.0000 \\
Penggunaan listrik per tenaga kerja & $0.1358^{* * *}$ & 0.0000 \\
Penggunaan air per tenaga kerja & $0.0803^{* * *}$ & 0.0000 \\
C & 5.7905 & \\
R-Square & & 0.7350 \\
Sig. Uji F & & 0.0000 \\
\hline${ }_{* * *}$. & &
\end{tabular}

*** signifikan pada taraf nyata $1 \%$

Sumber: Data Primer Diolah, 2020

Tabel 7

Sebaran Responden Berdasarkan Nilai Efisiensi

\begin{tabular}{lccccc}
\hline Efisiensi & Jumlah (orang) & Minimum & Maksimum & Rata-rata & Persentase (\%) \\
\hline $55-70 \%$ & 31 & 55.55 & 69.71 & 65.89 & 1.21 \\
$70-80 \%$ & 174 & 70.02 & 79.88 & 75.97 & 6.82 \\
$80-90 \%$ & 836 & 80.07 & 89.99 & 86.31 & 32.78 \\
$90-95 \%$ & 1004 & 90.01 & 94.99 & 92.55 & 39.37 \\
$95-99 \%$ & 505 & 95.00 & 99.93 & 97.28 & 19.80 \\
Total & 2550 & & & & 100.00 \\
Average & & & & & 84.99 \\
\hline
\end{tabular}

Sumber: Data Primer Diolah, 2020 
signifikan ini dibuktikan dalam hasil uji beda yang dapat dilihat pada Tabel 7.

Faktor yang memengaruhi efisiensi UMK industri makanan di Indonesia

Berdasarkan Tabel 10, variabel tingkat pendidikan, banyaknya hari kerja dan variabel rata-rata jam kerja per hari memiliki pengaruh negatif terhadap inefisiensi, sehingga dapat dikatakan variabel tersebut berpengaruh positif secara signifikan terhadap efisiensi. Sementara untuk variabel alokasi pasar dan variabel persentase modal sendiri memiliki koefisien dengan tanda positif yang berarti bahwa variabel tersebut memiliki pengaruh yang negatif signifikan terhadap efisiensi dikarenakan tanda positif menunjukkan pengaruh positif terhadap inefisiensi pada usaha UMK industri makanan di Indonesia.

Terkait dengan variabel alokasi pasar yang memiliki koefisien yang bertanda positif dapat diartikan bahwa untuk meningkatkan efisiensi usaha dari setiap tenaga kerja perusahaan lebih baik menjual produknya ke luar kabupaten atau luar provinsi. Jika perusahaan bisa menjual produknya dalam lingkup luar kabupaten atau luar provinsi kemungkinan akan membuat usaha tersebut lebih bersaing sehingga perusahaan harus meningkatkan efisiensi usahanya secara teknis agar perusahaan dapat bersaing dengan usaha lainnya. Jika dilihat pada Tabel 4, usaha skala kecil memiliki presentase sebaran alokasi pasar yang lebih luas dibandingkan usaha dengan skala mikro, sementara alokasi pasar dari sektor usaha mikro pada penelitian ini mayoritas adalah untuk memenuhi kebutuhan dalam lingkup kabupaten saja.

Variabel persentase modal sendiri berpengaruh secara negatif signifikan terhadap efisiensi. Hal ini karena koefisien memiliki tanda yang positif yaitu 0.0135

Tabel 8

Rata-rata Tingkat Efisiensi BerdasarkanJenis Usaha

\begin{tabular}{lcl}
\hline Jenis usaha (3 kode digit) & Jumlah (responden) & Rata-rata efisiensi (\%) \\
\hline 101-industri pengolahan daging & 19 & 92.55 \\
102-pengolahan ikan & 14 & 93.47 \\
103- pengolahan buah sayur, tempe & 325 & 90.68 \\
dan tahu kedelai & & \\
104-industri kopra, minyak goreng & 7 & 88.20 \\
kelapa & 64 & 87.23 \\
105-pengolahan susu & 44 & 94.07 \\
106-industri penggilingan padi & 2077 & 89.83 \\
107-produk roti, kue dan masakan & & \\
sejenisnya & 2550 & \\
Total &
\end{tabular}

Sumber: Data Primer Diolah, 2020

Tabel 9

Hasil Uji Beda dari Rata-rata Tingkat Efisiensi Berdasarkan Skala Usaha

\begin{tabular}{lll}
\hline Skala usaha & Jumlah (responden) & Rata-rata efisiensi (\%) \\
\hline Skala usaha mikro & 2362 & 89.57 \\
Skala usaha kecil & 188 & 95.22 \\
Total & 2550 & \\
Selisih & & $0.05^{* * *}$ \\
*** Signifikan pada taraf nyata 1\% &
\end{tabular}

Sumber: Data Primer Diolah, 2020 
Tabel 10

Hasil Output Perhitungan Inefisiensi Tenaga Kerja

\begin{tabular}{lcl}
\hline Variabel & Koefisien & P-value \\
\hline Modal per tenaga kerja & $0.0443^{* * *}$ & 0.000 \\
Penggunaan bahan bakar per tenaga kerja & $0.4425^{\star * *}$ & 0.000 \\
Penggunaan listrik per tenaga kerja & $0.1269^{* * *}$ & 0.000 \\
Penggunaan air per tenaga kerja & $0.0878^{* * *}$ & 0.000 \\
Faktor inefisiensi & & \\
Lama usaha & -0.0058 & 0.586 \\
Jenis kelamin & -0.0412 & 0.120 \\
Usia pengusaha & 0.0008 & 0.372 \\
Tingkat pendidikan & $-0.0221^{* * *}$ & 0.000 \\
Dummy kemitraan & 0.0473 & 0.276 \\
Alokasi pasar & $0.0039^{*}$ & 0.059 \\
Banyaknya hari kerja & $-0.0083^{* * *}$ & 0.000 \\
Rata-rata jam kerja per hari & $-0.0015^{* * *}$ & 0.000 \\
Persentase modal sendiri & $0.0135^{* *}$ & 0.021 \\
\hline *** &
\end{tabular}

${ }^{* * *}$ signifikansi pada taraf nyata $1 \%$

** signifikansi pada taraf nyata $5 \%$

* signifikansi pada taraf nyata $10 \%$

Sumber: Data Primer Diolah, 2020

dapat diartikan bahwa untuk meningkatkan efisiensi secara teknis justru persentase modal sendiri harus dikurangi atau dengan kata lain pengusaha disarankan meningkatkan modal yang dapat diperoleh dengan bantuan modal dari luar, Namun jika dilihat pada Tabel 5 terkait sebaran sumber modalnya dimana baik pengusaha pada skala mikro maupun skala kecil sebagian besar modal yang digunakan untuk keperluan usaha adalah modal sendiri, jumlah ini cukup tinggi yang berarti masih sangat sedikitnya pengusaha yang menggunakan modal bantuan dari pihak lain.

Terkait variabel tingkat pendidikan diduga jika pendidikan semakin tinggi maka nilai efisiensi teknis usaha akan semakin besar. Sementara variabel terkait karakteristik pemilik usaha seperti variabel usia, kemitraan, pengalaman usaha dan jenis kelamin tidak berpengaruh secara signifikan.

\section{SIMPULAN}

Sebagian besar produktivitas usaha pada skala mikro dan kecil (UMK) untuk industri makanan di Indonesia sudah efisien secara teknis, hal ini berarti setiap tenaga kerja pada UMK industri makanan telah menghasilkan produk secara efisien. Usaha kecil pada industri makanan memiliki nilai efisiensi teknis yang lebih tinggi dibanding dengan usaha pada skala mikro. Sementara faktor yang dapat meningkatkan efisiensi usaha diantaranya adalah perlunya peningkatan terhadap modal usaha, alokasi pemasaran serta peningkatan pengetahuan atau pendidikan baik secara formal maupun non formal yang bisa dilakukan melalui kegiatan pelatihan ataupun konsultasi. Pelatihan terkait dengan pencatatan pembukuan dan untuk peningkatan pangsa pasar seperti pelatihan packaging yang baik serta pelatihan penggunaan teknologi digital. Selain itu perlu diketahui seberapa jauh 
literasi digital yang sudah dipahami karena aspek teknologi juga merupakan hal yang harus diperhatikan.

\section{DAFTAR PUSTAKA}

Agung Pratama, M. (2015). Analisis Efektivitas Corporate Social Responsibility dalam Program Kemitraan Badan Usaha Milik Negara (Studi Kasus pada Perkembangan UMKM Mitra Binaan PT. Perkebunan Nusantara VII Unit Usaha Rejosari). Jurnal Natapraja, 1(1). https://doi. org/10.21831/jnp.v1i1.3444

Agustin, H. U., Rianto, W. H., \& Kusuma, H. (2018). Analisis Pengaruh Modal Dan Tenaga Kerja Terhadap Efisiensi Produksi Genteng Di Desa Sukorejo Kecamatan Gandusari Kabupaten Trenggalek. Jurnal IImu EKonomi JIE, 2(2), 194-205. Retrieved from http://ejournal.umm.ac.id/index.php/ jie/article/view/6979/5910

Alna, M. H. I., Hamzah, S., \& Rahmatia, R. (2018). Menyoal produktivitas Industri Kecil dan Menengah (IKM). Jurnal Ecces (Economics, Social, and Development Studies), 5(1), 80. https://doi.org/10.24252/ecc. v5i1.5238

Andika, C. S., \& Ardiyanti, R. R. R. (2014). Faktor-faktor Penghambat Pertumbuhan Usaha Mikro dan Kecil Pada Sektor Formal Dan Informal Di Jawa Timur. Jurnal Agora, 2(1).

Ariani, D., \& Suresmiathi, A. (2013). Pengaruh kualitas tenaga kerja, bantuan modal Usaha dan teknologi terhadap produktivitas kerja usaha mikro kecil dan menengah di Jimabaran. E-Jurnal Ekonomi Pembangunan Universitas Udayana, 2(2), 102-107.

Arifin, S., \& Firmansyah, F. (2017). Pengaruh Tingkat Pendidikan Dan Kesempatan Kerja Terhadap Pengangguran Di Provinsi Banten. Jurnal Ekonomi-Qu, 7(2). https://doi. org/10.35448/jequ.v7i2.4978
BPS. (2017). Hasil Pendaftaran Usaha/ Perusahaan Sensus Ekonomi 2016 Indonesia (BPS, ed.). Jakarta: Badan Pusat Statistik.

BPS. (2018). Perkembangan Indeks Produksi Triwulanan 2016-2018 Perkembangan Indeks Produksi Triwulanan Industri Mikro dan Kecil. Ddirektorat Statistik Indistri, 119 halaman.

Cherkos, T., Zegeye, M., Tilahun, S., \& Avvari, M. (2018). Examining significant factors in micro and small enterprises performance: case study in Amhara region, Ethiopia. Journal of Industrial Engineering International, 14(2), 227-239. https:// doi.org/10.1007/s40092-017-0221-y

Depkop. (2018). Perkembangan Data Usaha Mikro, Kecil , Menengah Dan Usaha Besar. In www.depkop.go.id (Vol. 2000).

Fanani, A., Anggraeni, L., \& Syaukat, Y. (2015). Pengaruh Kemitraan Terhadap Risiko Usaha tani Tembakau Di Kabupaten Bojonegoro Provinsi Jawa Timur. Jurnal Manajemen Dan Agribisnis, 12(3), 194-203. https://doi.org/10.17358/ jma.12.3.194

Furqon, D. F. (2018). Pengaruh Modal Usaha, Lama Usaha, dan Sikap Kewirausahaan Terhadap Pendapatan Pengusaha Lanting di Lemah Duwur Kecamatan KUwarasan Kabupaten Kebumen. Jurnal Pendidikan Dan Ekonomi, 7(1), 51-59. Retrieved from http:// www.albayan.ae

Hidayati, D. R. (2016). Strategi Komunikasi Pemasaran Usaha Skala Mikro (Micro Enterprise) KUB Bajrah Gunah Klampis Bangkalan Pada Produk Terasi, Petis dan Kerupuk Ikan. Agriekonomika, 5, 104-112. 
Kadim, D. N., Masinambouw, V. A., \& Sumual, J. I. (2017). Pengaruh Jumlah Produksi, Pengalaman Usaha Dan Jenis Kelamin Terhadap Pendapatan Usaha Tukang Jahit Di Presiden Shopping Center Kecamatan Wenang Kota Manado. Jurnal Berkala IImiah Efisiensi, 17(02), 1-11.

Kementerian Koperasi dan Usaha Kecil Menengah. (2017). Perkembangan data usaha mikro, kecil, menengah (umkm) dan usaha besar (ub) tahun 2016 - 2017. Depkop, (1), 2. Retrieved from Sumber Kementerian Koperasi Dan UKM

Kinyua, A. N. (2014). Factors Affecting the Performance of Small and Medium Enterprises in the Jua Kali Sector In Nakuru Town, Kenya. IOSR Journal of Business and Management, 16(1), 80-93. https:// doi.org/10.9790/487x-16148093

Leza, T., Rajaan, S., \& Kuma, B. (2016). Determinant of Technical Efficiencies of Micro and Small Enterprises in Wolaita Zone, Ethiopia. Journal of Economics and Sustainable Development Www.liste.Org ISSN, 7(21). Retrieved from www.iiste.org

Óhegyi, K., Bene, A., \& Csernak, J. (2013). Competitiveness Analysis of the Food Processing Smes. International Journal of Business and Management Studies, 5(1), 21-30.

Pilar, P. G., Marta, A. P., \& Antonio, A. (2018). Profit efficiency and its determinants in small and mediumsized enterprises in Spain. $B R Q$ Business Research Quarterly, 21(4), 238-250. https://doi.org/10.1016/j. brq.2018.08.003
Purwanto, P., Manongga, D., \& A. Ineke Pakereng, M. (2014). Efficiency of Small- and Medium-sized Tofu Enterprises (SME) in Salatiga using Data Envelopment Analysis (DEA). International Journal of Computer Applications, 91(12), 44-50. https:// doi.org/10.5120/15936-5252

Quinn, B., McKitterick, L., McAdam, R., \& Dunn, A. (2014). Special Issue: The competitiveness of SMEs in the food sector - exploring possibilities for growth Introduction. International Journal of Entrepreneurship and Innovation, 15(3), 143-145. https:// doi.org/10.5367/ijei.2014.0158

Robleh, M. H. (2017). Factors Influencing the Performance of Small. Global Journal of Management and Business Research: A Administration and Management, 17(5), 15-35.

Septiana.L.Siahaya. (2018). Pengaruh Gender Dan Lama Usaha Terhadap Produktivitas. Jurnal Maneksi, 7(2), 94-99.

Sholeh, Y. (2017). Peranan Home Industri Emping Melinjo Dalam Meningkatkan Pendapatan Keluarga Di Kecamatan Burneh Kabupaten Bangkalan. Agriekonomika, 6(1). https://doi. org/10.21107/agriekonomika. v6i1.1905

Soriano, F. A., Villano, R. A., Fleming, E. M., \& Battese, G. E. (2019). What's driving innovation in small businesses in Australia? The case of the food industry. Australian Journal of Agricultural and Resource Economics, 63(1), 39-71. https://doi. org/10.1111/1467-8489.12284 
170 | Syifa Fauziah dkk., Produktivitas Usaha Mikro dan Kecil Industri Makanan di Indonesia

Susianto, Y., Ayuni, S., Larasaty, P., Utari, T., \& Dewi, N. (2014). Pengaruh Setiyawati, N., Saputri, V. G., Hastuti, A., ... Kamala, S. (2019). Analisis Hasil SE2016 Lanjutan Analisis Daya Saing Usaha Industri Pengolahan (Rustam \& S. Ayuni, eds.). Jakarta: Badan Pusat Statistik. Modal, Tingkat Pendidikan Dan Teknologi Terhadap Pendapatan Usaha Mikro Kecil Dan Menengah (Umkm) Di Kawasan Imam Bonjol Denpasar Barat. E-Jurnal Ekonomi Pembangunan Universitas Udayana, 3(12), 576-585. 